\title{
When Geography Matters: The potential role of Saudi Arabia's Geographical Branding in Promoting FDI
}

\author{
Megbel Aleidan ${ }^{1}$ \\ ${ }^{1}$ King Faisal University, School of Business, Saudi Arabia \\ Correspondence: Megbel Aleidan, King Faisal University, School of Business, Saudi Arabia. E-mail: \\ maliedan@kfu.edu.sa
}

Received: October 20, 2018

Accepted: November 28, 2018

Online Published: December 18, 2018

doi:10.5539/ijbm.v14n1p64

URL: https://doi.org/10.5539/ijbm.v14n1p64

\begin{abstract}
Background: Nation branding's role of luring foreign investments should be maximized to the extent, in which the entire dimensions of host countries are adequately harnessed in the development of their image. Geography therefore represents a dimension of a vital importance to nation branding given into account its association with a group of locational advantages.
\end{abstract}

Objective: To evaluate the potential role of Saudi Arabia's geographical branding in promoting FDI.

Methods: The current study investigated foreign companies seeking to enter the Saudi markets or expand their business within the country. A total of 234 CEOs, general managers and those who hold similar positions with a direct involvement in international affairs were polled in the study. Structural Equation Modeling (SEM) was used to analyze the data collected via AMOS 20.

Results: It has been revealed that the connecting location, the logistic importance of Saudi Arabia and its closes to important markets showed direct effects on geographical branding. The study has also found that geographical branding meditated the effects of its three pillars on the inward foreign direct investments of Saudi Arabia.

Discussion and Conclusion: The current study added a new vigor to the literature of nation branding through its ability to shed light on the geographical aspect of it and find correlations between geography and FDI from a nation branding perspective.

Keywords: Nation Branding, Country Image, Geographical Branding, FDI Promotion.

\section{Introduction}

Branding is carried out by following a systematic approach that requires communicating the value proposition of the country for long-term goals (Dogan \& Petkovic, 2016). Achieving and creating brand image is particularly easier for the countries that enjoys stability in terms of politics and economy. However, other countries with irregular economic and political instability are required to exert greater efforts to promote their brand image(Dogan \& Petkovic, 2016). This implied that the country image could be considered as a branding determinant with a direct effect on the country's reputation and its investment profile. From a reputation perspective, the image of a country facilitates the enhancement of its reputation while it plays a crucial role in enhancing its investment profile through attracting a great deal of outward invesments (Correia Loureiro, Veríssimo, \& Cayolla, 2013).

As a consequence, countries are encouraged to consider rebranding as a tool to aid them creating a fresh image through their positive values and ownership advantages (Dogan \& Petkovic, 2016). In such context, the example of Denmark can be of significance, who lost its brand image after the Cartoon Crisis in 2005 (Merkelsen \& Rasmussen, 2015). The crises negatively affected the national image of the country; therefore, it was imperative for the Danish government to formulate a nation brand initiative for reconstituting its image globally3. Meaning that the country ability to enhance its investment profile globally is not only determined by its political and economic stability, a part of such ability is connected to its image and how to position itself in the minds of international investors (Kalamova \& Konrad, 2010).

Although the latest trends in nation branding mainly concentrates on the promotion of the nation's values (Dogan \& Petkovic, 2016;Avraham, 2018), the nation's geography can also hold a specific significance when it comes to 
marketing that nation in the global arena (Browning, \& Ferraz de Oliveira, 2017). All attributes of public and private life are invaded in the practice of branding7. Substantial amount of efforts and resources are being devoted to the progression of place marketing and place branding strategies in the case of geographical locations (Arkenbout, 2015).

It is well-established that natural public and communal can conform delicacy and adaptation even though integrating marketing tools from the private sector to geographic locations (Vuignier, 2016). The promotion of a place, products and businesses of a nation is proven from the process of applying branding principles to a geographical location. Geography and regional development, rural closeness to important markets, and rural development examine the republic regional brands (Margarisová, \& Vokáčová, 2016). The nation branding is entirely oriented toward global markets with respect to culturally, economically and politically aspects as determinants of the geographically decentralized location of a country. Nation branding has the potential to play an essential and vital role in the economic, social, cultural and political developments of regions, cities, and countries and; therefore, it can be created on diverse geographical scales across and throughout administrative borders (Del Percio, 2016).

Foreign Direct Investment (FDI) is achieved through trade openness, as explained by the state-of-the-art theory, which defines the direction and size of FDI flow4. Given the role played by FDI in terms of increasing the economic growth of countries, these countries must detect new ways to harness their brands for influencing the FDI flows into their markets (Margarisová, \& Vokáčová, 2016; Del Percio, 2016; Papadopoulos, \& Hamzaoui-Essoussi, 2015). Such flows not only bring financial resources to the host countries, most importantly they contribute to transferring of industrial and technological expertise, imitating of tacit knowledge and know-how, developing managerial skills and promoting the citizen's welfare. Accordingly, a nation that seeks to maximize its FDI gains, is required to innovatively introduce itself to the entire world through a multiple-dimension brand, in which geography is an integral part of it (Kam, \& Tse, 2018; Frig, \& Sorsa, 2018).

Saudi Arabia (the country under investigation in this study), seems to be an interesting case of study when it comes to nation branding from a geographical perspective for two considerations. First, the country's classification as "semi-arid" might be seen as an obstacle of capitalizing on geography in promoting itself (Anyanwu, 2017). Second, the country's possession of the massive proven oil reserves might not encourage foreign investors to explore Saudi Arabia's other locational advantages. These considerations pave the way for the author to how do investors assess the geographical values of Saudi Arabia and how the country can leverage its untapped geography to rebrand its self.

This orientation seems vital given into account the non-existence of empirical evidences on the geographical brand of Saudi Arabia and its association with FDI. It is also vital when to it comes to the need of the governmental bodies in Saudi Arabia to be informed and guided by empirical evidences while developing an effective nation branding strategy. The country's attempt to get rid of its oil serotypes through the launch of the promising 2030 vision under the leadership of Crown Prince Mohammed bin Salman, is also another motivation to figure out how Saudi Arabia can redefine its investment and economic-based brand by putting geography at the heart of it. All such factors facilitate the current study's efforts in precisely evaluating the role of Saudi Arabia's geographical branding in promoting FDI.

\section{Literature Review}

\subsection{Nation Branding}

The concept of nation branding is traced from four different sources, namely, place or destination branding (Kotler, Haider, \& Rein, 1993; Kotler, Haider, \& Rein, 1993; Morgan, Pritchard, \& Piggott, 2002), national identity (Smith, 1991; Bond, 2006), country of origin (Papadopoulos, \& Heslop, 2002) and public diplomacy (Van Ham, 2003; Matiza, \& Oni, 2014). Nation branding is associated with an entire image of a country on the international forum to cover economic, political and cultural dimensions as compared to country of origin and place branding, which promote particular economic interests such as closeness to important markets, inward investment and export. Thereby, nation branding is demonstrated as a mere platform of branding tools and strategies for nation states.

Likewise, the occurrence of nation branding allows a government or an organization to change the image of a nation by using its power. The attitudes, identity, image or behavior of a nation is changed or altered positively through the application of nation branding. Correspondingly, the importance of nation branding in the economic and investment perspective is enlightened from six different dimensions, namely closeness to important markets, exports, logistic importance, geographical branding, people and culture (Del Percio, 2016). It is well-established that the ultimate economic and investment decision of a country is demonstrated from an unfavorable image of a 
country (Papadopoulos \& Heslop, 2002). The role of nation branding in economic and investment promotion is demonstrated as an important stage in the investment promotion success (Matiza, \& Oni, 2014).

A positive perception of an ideal business location is globally developed from the image-building process, which ultimately turns a country into a resonant and a trustworthy brand among investors (Melissen, 2005). The nation branding is at the optimum level of investment promotion, specifically for nations considered as new or small to foreign direct investment attraction. Nations receiving limited or negative international media coverage have gone through substantial economic or political reforms 24,25 . The incremental development of nation branding concept facilitated the conduction of several studies in which counties were examined according to their nation branding approaches.

One example of these studies can be found in the study of Odia and Isibor (Odia \& Isibor, 2014), in which they strategically evaluate the nation-branding approach of Nigeria. As an outcome of their study, a model was developed, named Nation Brand Strategic Management Model with the objective of building the image of Nigeria. Another example of these studies can be found in the study of Kaneva and Popescu (Kaneva \& Popescu, 2011) in which they examine the attempt made by Romania and Bulgaria to reconstitute their brands following the collapse of communism in 1989. In their study, they highlighted the nation branding programs that were developed by the Bulgarian and Romanian governments to articulate a new image for reviving the national economies of the both countries.

The nation branding process is usually characterized by it continues nature and its need to be cyclically reviewed for differentiation purposes. Andrei (Andrei, 2016) has asserted that a holistic approach is included by nation brand managers when developing international positioning strategy, which allows their country to differentiate its offerings from its competitors. Economy, closeness to important markets, geography and nature, society, science and technology, government, and culture and patrimony are the dimensions, which explain the impact of nation branding on country image and economy.

Correspondingly, Jordan (Jordan, 2014) argued that nation branding is a phenomenon opted by governments to engage themselves in self-conscious activities that develop a specific image of the nation state. It is also identified as a commercial practice that reposition and redefine a nation state throughout the globalization. Likewise, Laszlo (Laszlo, 2014) referred nation branding as a national and cultural commodification through globalization conditions, but also as an altered nationalism form or measure to shape the neoliberal market capitalism. It can be also seen as ethnocratic discursive structures of the state or a transformation of the national community. Moreover, as Matiza and Oni (Matiza \& Oni, 2014) assert, nation branding can be interpreted as the active management and projection of a nation's identity.

\subsection{Nation Branding from a Geographical Perspective}

The concept of branding is being applied to a geographical entity based on the geographical nomenclature of the place. Che-Ha et al. have indicated towards the perceptions and emotions of people created by geography, nature, position, climate and cities toward the nation branding. In the similar context, Gunnarsson and Holmströ have pointed that geographic labeling is used to predict product quality, reliability and status toward the country. Place branding and place marketing issues are also addressed through the geography approach.

The geography approach offers conceptual reflections on place, geospatial relationships, discussions and space at the macro level. It also addresses questions of land planning and architecture at the micro level. Imran (Imran, 2018) has argued an important role of geography in promoting nation branding and revealed that nation branding campaign activities connect to national image, strategic location, folklore, traditions, natural beauty, human capital, unique history, culture, and social and moral values. This proves that geography and location advantages play a critical role in improving the nation branding of a particular country.

\subsection{Geographical Nation Branding as a Catalyst of FDI}

Nation branding cannot be assessed without considering the geographical importance of a country. As mentioned in the report by Nation Brand (Nation Brands, 2017), firms usually seek to invest internationally on the basis of the host country's political and economic stability. However, the geographical location of the host country and its market size should possess equal importance when it comes luring foreign investments to that country. Therefore, governments are urged to consider geographical branding as an FDI catalyst. Similarly, Pike (Pike, 2009) has ascertained that FDI is attracted and the brightest political influence is wielded through strong brands.

The uneven development is contributed through the geographical entanglement, which specifically focuses on reinforcing, embodying, amplifying and creating the competitive sociospatial relations between places and spaces. Correspondingly, the term nation branding is associated with the promotional activities of a country, 
marking the region with a diverse identity and contextualizing the platform of marketing communications from an inside-outside approach (Handayani \& Rashid, 2013; Wilson, R. T., Baack, \& Donald, 2014; Yin, Ye, \& Xu, 2014).

The geographical location of the country contributes significantly towards its FDI as it increases the share of the country economy and reduces its involvement in the international trade (Gunnarsson, \& Holmström, 2017). The location also adds to its resources, as the larger supply of natural resources reduces its dependency, making it self-sufficient. This portrays a strong economy image of the nation positively impacting the FDI. Though, the FDI in it is negatively impacted as it lowers the level of trade openness (Imran, 2018). The imports of the nation also decline based on its self-sufficiency aspect which may be reciprocated by its nearby countries, decreasing the likelihood of drawing foreign investment.

\subsection{Direct Effects Hypotheses}

From a geographical nation branding, there are a number of factors that might have a direct impact on the FDI, such as connecting location, closeness to important markets, and logistic importance. The association between the resources and capabilities of a country is dependent on its geographical proximity, location and closeness to market where it operates its activities (Alfaro \& Chauvin, 2016). The benefits of specific geographic locations with respect to their capabilities and resources are combined to develop and improve existing competitive advantages (Hurn, 2016).

Previously, studies have mentioned that geographical location plays a vital role in influencing the scale and nature of FDI. Similarly, strategic assets and the agglomeration of foreign investments were other factors that respond to the promotion of FDI in the host country (Žugić \& Konatar, 2018). The decisions made by the host country toward the FDI promotion are entirely based on the national and regional boundaries. Likewise, client-following objectives and market-seeking objectives were also attracting factors as the location determinants toward the promotion of FDI.

The objectives of developing clear, distinct and parsimonious factors of FDI promotion are proven from the strategic motives adopted by a host country. The most favorable business environment seeking motives include efficiency seeing, strategic motives, closeness to market, geographical location and logistic importance (Martínez, Galván, \& Lafuente, 2014). A host country is allowed to adhere the relative impact of FDI motives considering the overall investment trends and relaxed export-oriented motives. It has been witnessed that market size and distance are entirely important in identifying where countries ascertain their foreign affiliates.

The countries with the biggest markets were adjusted for market size, distance, a large share of investment, and a large share of investment stays close to home. The geographical branding of a country is an intangible phenomenon, associated with its image for the enhancement of international trade as well as relations. This helps the country in attracting the foreign direct investment in the country essential or the economic growth (Dinnie, 2015).

The FDI is significantly impacted by the closeness the country has towards the market, as the optimal site can improve its location attributes increasing its profitability prospects in the future. The country closeness to market allows it to observe the alterations which are taking place in the market. It also mitigates the cost associated in terms of transportation (Vela, 2013).

Logistics' cost is linked with transportation and the import protection placed in the country. The low-cost associated with logistics allows the country to improve its position attractively and customer service. These are critical as they provide the necessary infrastructure including the transportation, communication, availability of resources44. Improve logistic capability of the country increases the income of the government facilitating the country in overcoming the infrastructure weakness such as transportation (Skinner, 2008).

The strategic location and the FDI are closely related which play an important role in the nation branding. Investors study the development of the economy as well as the individual sector market seeking opportunities for their investment decision. The characteristics of the country such as its size, GDP per capita, the potential for growth and the middle-class size are some of the determinants which improve the country likelihood of receiving more investments (El Banna, Hamzaoui-Essoussi, \& Papadopoulos, 2017).

To this end, the following direct hypotheses can be developed;

Hla: The connecting location of Saudi Arabia with three continents will have a direct positive impact on its geographical brand.

$H 1 b$ : The logistic importance of Saudi Arabia will have a direct positive impact on its geographical brand. 
H1c: The closeness of Saudi Arabia to important markets will have a direct positive impact on its geographical brand.

H2a: The connecting location of Saudi Arabia with three continents will have a direct positive impact on its inward FDI.

$H 2 b$ : The logistic importance of Saudi Arabia will have a direct positive impact on its inward FDI.

H2c: The closeness of Saudi Arabia to important markets will have a direct positive impact on its inward FDI.

\subsection{Indirect Effects Hypotheses}

Geography plays an important role in improving the nation branding of a country. The image of a country is highly dependent on few factors that accounts for the nation branding, such as place-geography of the country, tourist attractions, people-races culture, languages, pictures of images, history, and natural resources etc. Therefore, geographical perspective cannot be ignored while developing strategies for nation branding.

To this end, Vela proposed that different geographical spaces possess different unique identities, in which each identity is branded exclusively to a particular geographical space. The study reported that due to the rising competition between territories, it has become extensively important for nations to build their brand images with the consideration of different geographical spaces. Similar to this, Pike revealed that the reinforcement and the articulation of economic and investment inequalities are entirely associated with the geographically entangled brands.

Geography is required to be placed on the heart of any nation branding activities not only for emphasizing the strategic importance of a specific country but also for highlighting the significance of approaching its knowledge-based assets, accessing its distinct cultures, fulfilling its consumer demands, and leveraging its institutional strategic and synergistic assets (Skinner, 2008).

The necessity of paying a specific attention to geography while exercising nation branding activities are the fact that FDI has strong geographic preference in major metropolitan cities and prosperous coastal provinces. This increasing importance of geography and location choice for foreign investments is strongly indicated in the new economic geography literature (El Banna, Hamzaoui-Essoussi, \& Papadopoulos, 2017).

H3a: Geographical branding mediates the effect of the connecting location of Saudi Arabia with three continents on FDI.

H3b: Geographical branding mediates the effect of the logistic importance of Saudi Arabia on FDI.

H3c: Geographical branding mediates the effect of the closeness of Saudi Arabia to important markets on FDI.

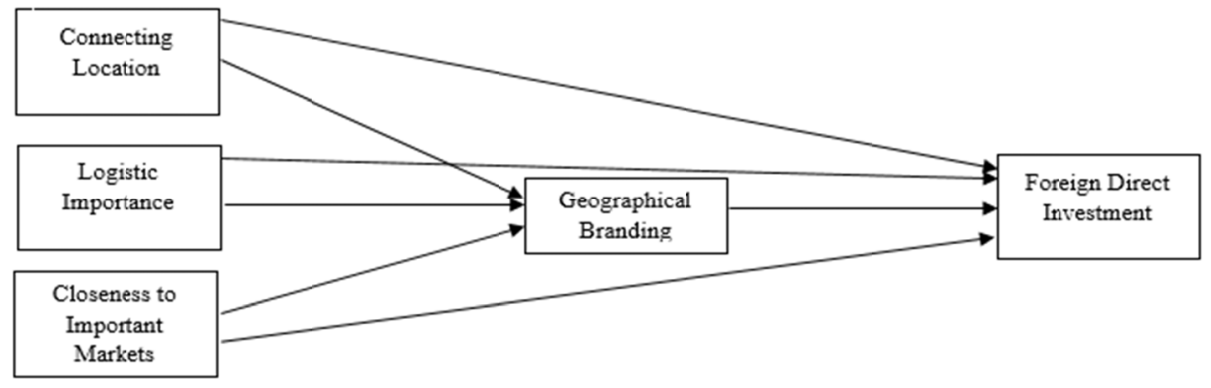

Figure 1. Conceptual Framework

\section{Methodology}

\subsection{Research Context, Sampling and Data Collection}

The study has evaluated the geographical nation branding and its impact on the foreign direct investment in the country of Saudi Arabia. The sample companies of the study are foreign companies seeking to enter the Saudi markets or those seeking to expand their business in within the country. Both mail and online surveys were used to collect the data from the selected sample of the study. To attain the objective of the study, respondents were limited to the general managers, CEOs or any appointed representative of the company possessing the experience related to foreign direct investment.

Before administrating the questionnaires, the selected respondents were screened to check if they are according 
to the criteria selected for the study. Those who did not comply with the criteria were omitted from the study. A total of (Grdic \& Radic, 2012) questionnaires were distributed among the sample size through mail and Internet. Only 247 questionnaires were returned, in which 225 were completed via mail and the remaining were completed via Internet.

Among these questionnaires, 13 were omitted because they were improperly filled, in which the aggregate questionnaires were reduced to 234. The sample consisted of 177 males and 57 females. Mostly respondents were found to be in the age range of 30-44 years with a work experience of 5-10 years with at least undergraduate degrees. The respondents included 22 CEOs, 99 general managers, 30 production managers, 19 financial managers, 33 marketing managers and 31 others.

\subsection{Measures and Instrument Development}

The questionnaire was divided into three sections, namely; organizational information of the sampling companies, geographical branding and its three pillars (connecting location, closeness to important markets, and logistic importance) and the impact of geographical branding on FDI. Table 1 provides detailed information on the constructs and items that were included in the process of questionnaire development.

The first section is based on the information related to the company and its association with the investment in Saudi Arabia (Q1-Q6). The second section is based on the questions related to the geographical nation branding (Q7-Q10). The third section comprises of the information related to the logistic importance of Saudi Arabia with questions from Q11-Q14.

The fourth section comprises of the questions related to the closeness of Saudi Arabia to important markets with questions from (Q15-Q17). The fifth section comprises of the questions related the connecting location of Saudi Arabia with questions from Q18-Q21. The last section is related to the impact of geographical nation branding and its pillars on FDI promotion with nine questions (Q22-30).

Table 1. Constructs, items and confirmatory factor analysis loadings

\begin{tabular}{lcc}
\hline Constructs & Estimate & Prob. \\
\hline Geographical Branding & 0.81 & 0.00 \\
& 0.74 & 0.00 \\
Connecting location & 0.80 & 0.00 \\
& 0.76 & 0.00 \\
Logistic importance & 0.82 & 0.00 \\
& 0.83 & 0.00 \\
Closeness to important markets & 0.95 & 0.00 \\
& 0.89 & 0.00 \\
& 0.70 & 0.00 \\
& 0.86 & 0.00 \\
& 0.81 & 0.00 \\
& 0.85 & 0.00 \\
& 0.66 & 0.00 \\
& 0.63 & 0.00 \\
& 1.01 & 0.00 \\
& 0.59 & 0.00 \\
& 0.81 & 0.00 \\
\hline
\end{tabular}

\subsection{Pre-Test and Pilot Study}

A pilot study was conducted in the form of a pre-test, to check the reliability and authenticity of the selected measures for the study. The pilot testing involved three practitioners as participants of the following study. After checking the content and face validity, the internal consistency of the constructs was also checked. The pilot survey involved sending email questionnaires to the general managers. 
A total of 250 questionnaires were administered to the general managers of the companies. Only 45 questionnaires were received properly filled. The results of the pilot study suggested that the internal consistency of the selected constructs was high, which showed that the study could proceed to the next step.

\section{Results}

\subsection{Confirmatory Factor Analysis (CFA)}

Structural equation modeling (SEM) has been used to analyze the data collected from the participants (234 responses). CFA, direct and mediation results were computed through SEM using AMOS 20 on all the given constructs of the study, including geographical nation branding, logistic importance, connecting location, closeness to important markets and FDI promotion.

A total of 22 constructs and sub-constructs were subjected to the CFA model to develop the construct validity and reliability of the established items. From the initial loadings, it has been noted that four items showed a poor fit and; therefore, dropped from the final measurement model. In this case, a total of 18 items were incorporated in the final measurement model signifying five constructs with an appropriate fit.

Table 2. Confirmatory Factor Analysis Loadings

\begin{tabular}{lcccccc}
\hline & Convergent Validity & \multicolumn{2}{c}{$\begin{array}{c}\text { Another type of } \\
\text { Discriminant Validity }\end{array}$} & \multicolumn{2}{c}{ Discriminant Validity using Fornell and Larcker 1981 } \\
Criterion
\end{tabular}

\subsection{Structural model-Direct Effects}

AMOS has been used to test direct effects with an acceptable good fit $(\mathrm{CMIN} / \mathrm{DF}=2.103 ; \mathrm{CFI}=0.922, \mathrm{GFI}=$ 0.8 (Mac-Dermott \& Mornah, 2015); AGFI =0.821; RMSEA = 0.071) (Table 3). From the findings of direct effects, it has been revealed that all the three pillars showed direct effects on geographical branding. Meaning that H1a, H1b, and H1c are supported. Similarly, the connecting location of Saudi Arabia shows a direct effect on its inward FDI, supported H2a $(\mathrm{p}=0.01)$.

A significant direct effect of the logistic importance of Saudi Arabia on FDI has been found and supported H2b $(\mathrm{p}=0.01)$. The closeness of Saudi Arabia to important markets shows a significant direct effect on FDI, supporting $\mathrm{H} 2 \mathrm{c}(\mathrm{p}=0.01)$.

Table 3. Hypothesis Results and Summary for Direct Effects

\begin{tabular}{lcccc}
\hline Direct Paths & Estimate & Std. Error & T-Statistics & Prob. \\
\hline Closeness to important markets $\rightarrow$ Geographical branding & -0.02 & 0.07 & -0.26 & 0.79 \\
Logistic importance $\rightarrow$ Geographical branding & 0.37 & 0.07 & 5.05 & 0.01 \\
Connecting location $\rightarrow$ Geographical branding & 0.26 & 0.08 & 3.30 & 0.01 \\
Connecting Location $\rightarrow$ FDI & 0.12 & 0.07 & 1.78 & 0.01 \\
Logistic Importance $\rightarrow$ FDI & 0.25 & 0.07 & 4.31 & 0.01 \\
Closeness to Important Markets $\rightarrow$ FDI & 0.33 & 0.08 & 2.12 & 0.01 \\
\hline
\end{tabular}

\subsection{Mediation Results}

AMOS version 20 was used to test the mediation effects of geographical branding on the connecting location, 
the logistic importance and closeness to important markets when it comes to the promotion of inward FDI in Saudi Arabia. The results (Table 4) show full mediation effects of the geographical branding $(p=0.03)$. They also show that geographical branding has mediated the effect of the connecting location of Saudi Arabia with three continents on FDI, supporting H3a $(p=0.01)$.

Geographical branding has mediated the effect of the logistic importance of Saudi Arabia on FDI, supporting H3b $(p=0.01)$. Geographical branding has mediated the effect of the closeness of Saudi Arabia to important markets on FDI, supporting H3c $(\mathrm{p}=0.01)$.

Table 4. Hypothesis Results and Summary for Mediation Effects

\begin{tabular}{lcccc}
\hline Indirect Paths & Estimate & Std. Error & T-Statistics & Prob. \\
\hline Connecting Location $\rightarrow$ Geographical Branding $\rightarrow$ FDI & 0.12 & 0.03 & 0.78 & 0.01 \\
Logistic Importance $\rightarrow$ Geographical Branding $\rightarrow$ FDI & 0.15 & 0.03 & 0.31 & 0.01 \\
Closeness to Important Markets $\rightarrow$ Geographical Branding $\rightarrow$ FDI & 0.13 & 0.03 & 0.12 & 0.01 \\
Geographical branding $\rightarrow$ FDI & 0.01 & 0.01 & 0.60 & 0.03 \\
\hline
\end{tabular}

\section{Discussion and Conclusion}

\subsection{Theoretical Implications}

The theoretical implications in the present study have emphasized the effect caused by the geographical branding on the promotion of FDI. It is a well-established fact that FDI is crucial for the company towards to leverage its economy development and strengthen its position in the world, in terms of the capital it possesses. The opportunity provides an interaction among the investors, the regional network competence, and objectives 49.

By connecting location, improving logistics as well as closeness with the market, the geographical branding can create a shared place. The engagement possibilities of the stakeholder as well as their commitment with the brand can be enhanced. Whereas, the opportunities for investment can be realized based on the FDI process, improving the working capacity of the region networks, their competence, along with the objective set, enhancing their scope and reach50.

The theoretical framework highlights the continual aspect, where geographical branding serves as the source for the identification of the new opportunities, where each individual makes an investment contribute towards the place image. Additionally, this also helps establishing a smooth path for communication and logistics mitigating the distance frictions. The closeness to market places also allows the regional businessmen to recognize the potential along with their role in the FDI process (DCMS, 2011).

The close proximity with the market benefits it from knowledge spillovers as well as increases its absorptive capacity in terms of technological innovation. The close proximity with the foreign market allows considering its size as well the regional market. The export function of economies can be observed in such cases, which allows it to execute decisions based on the profit maximization opportunities. This factor allows the country economy to form a shared pool of skilled labor who are specialized input supplier possessing the necessary capabilities. It advances the collaborative practice as well as capabilities embedded in the firm of the country.

The effective management of the company resources increase the profitability prospects of the country. In the context of the national building, the access to market serves as a catalyst and eradicator of trade frictions at the same time. This impacts the FDI in a positive way as it positively responds to higher trade barriers in the country. The local industries also developed based on the value-added logistic activities amplifying the GDP earned by the country and the trade of the domestic goods.

The increase in the trading volume expands the financial inflows as the economy operations become more robust. The independent working of the country allows the firm the opportunity to increase its FDI. Moreover, the private sector effective performance is also important for increasing the economic stability in the country. Further, the types of FDI can be targeted through it, which parameters and various corporate taxes must be reviewed.

With the increase in national branding new trends and changes are to arrive at a more frequent rate, where the employment and the production capacity will improve with time. The increase of inward FDI depicts a positive image of the economy as a whole and also helps in improving the network within the country (Huh, 2002). With the integration of geography in the national branding, the regional firms control regulation can also be enhanced towards enhancement of its profit, and benefit provided to the owner. 
The physical characteristics such as the location with a stable political environment are the key features for improving the FDI advent in the country. The investors are particularly interested in the activities such as the indirect expropriation, punitive taxation, and regulations on the returns. The strategic location of the country lures the FDI based on its integration of the new technologies, increasing cooperation and effective distribution channels.

Additionally, the creation of vertical linkages in the sector within the networks, in which the existing clients are used for making the entry in the market creating an agglomeration effect and FDI clusters, such as the automobile manufacturer foreign investment compels the manufacturer components foreign investment as well. The human capital features and economic diversity makes the country location more strategic. Creation of export-platform for FDI allows the country to not only supply to the local market but also the surrounding nations. Moreover, the reduced cost for labor, connection of the location with other markets as well as the objectivity of the residing people plays a key role in increasing FDI.

Using AMOS and Structural equation modeling (SEM), the study provides that the absorptive capability of the country also enhances based on its integration of geographic component in national branding. The innovative sources, their value and commercial exploitation is also enhanced, increasing the network resources as well as capabilities. It also assists in the joint development of product and processes providing an effective execution of the total quality management and JIT (just-in-time) practices (World Values Survey, 2005-2006).

The study provides that the stakeholder coordinate work practice takes place improving the long-term commitment and promotion of particular national interest. The location through this theoretical framework is viewed as the capability builder directing the country towards the development of rare skills and innovation (International Living, 2010). Furthermore, the image of the country enhancing its prospects for improved export sales. The stereotypes also get catered with geographical perspective integration in the national branding, which serve as a source of information for deriving the investment potential in a particular country.

The productive capacity of the country management at the national level also improves, depicting to the international world about its economic development and strengthen strategic position. It is implied by the theoretical framework that the integration of the geography into the concept of nation branding improves local capability, its infrastructure, makes investment promotion better and directs more FDI towards its, highlighting the positive results.

\subsection{Managerial and Governmental Implications}

Countries usually do not grasp the opportunity offered by their geography while branding themselves to the world. Therefore, governments need to absorb the importance of this missed opportunity by placing geography at the center of their national brand. Thus, a large portion of their countries' branding strategy and activities can be geographically oriented. The geographical structure and regulation allow the country to liberalize its market and improve the participation of the private sector. Moreover, this promotes the infrastructure financing and capture the capabilities of the top logistical market.

Considering the connecting location aspect, the interconnectivity of the places increase, and close association develop between the places, encourages active funding, management as well as governmental control on the organization. The positive integration among the location allows the promotion of favorable reputation with a large target audience. The understanding gets promoted at a collective level, wide cooperation is achieved and execution of long-term procedures and market expansion occurs developing the country as a brand with favorable reputation.

This capability allows foreign investors to observe the country as a bridge to approach huge number of customers and compel them to engage in its product, providing economic gain. It also sustains the active participation of the internal stakeholders constituting of government officials along with local residents improving the country general image and reputation in the in internationalized market.

The pillar of strategically logistic importance provides the country with the strategies to reduce its cost of transporting good, improve its service deliverance and reducing the investment made on the logistic system. It focuses on the leveraging of the returns receive on investment, through unity. The strategic logistic capabilities allow the company to improve the level of revenue and reduce the cost incurred. This allowed the foreign company to use it as their exporting hub, for their product worldwide dissemination. This helps the company to tab into regional and international industries supplying to the large customer database such as the assimilation of the Agritech and automotive components increase Saudi reach to overall region of Middle East.

The closeness to the market allows the country to increase its reach to other countries, and promotes the other 
foreign investors to expand their business in the region. This allows the company to not only amplify its reach but also penetrate into other parts of the country based on the geographical integration that lies within the country. The information on the crucial markets can be reached in an effective manner allowing the company to regulate its investment in a favorable way supplying to every customer need. Through it, the future strategies can also be devised for expansion based on the feature of the country, ensuring sustainment of competitive through the supply of superior products

\section{Limitations and Future Research}

Given into account the non-existence of solid empirical evidences on geographical nation branding and its association with FDI, the current study's ability to conduct a systematic literature review with the purpose of emphasizing the findings of the previously conducted studies in the subject under investigation was hindered. Moreover, due to the novelty of the concept of geographical branding and its ability to be further extended, this study was only able to consider three aspects of it, namely, the connecting location, the logistic importance and the closeness to important markets.

Although, this can be seen as a limitation, it however opens the door for future researchers to consider other aspects of the geographical branding. The current study's attempt to detect a correlation between geographical branding and FDI, paves the road for the fellow researchers to find new avenues, in which they can connect geographical branding with other concepts, specifically in the fields of economic and commercial diplomacy.

\section{Acknowledgements}

The author is very thankful to all the associated personnel in any reference that contributed in/for the purpose of this research. Further, this research holds no conflict of interest and is not funded through any source.

\section{References}

Alfaro, L., \& Chauvin, J. (2016). Foreign Direct Investment, Finance, and Economic Development.

Anderson, J., \& Sutherland, D. (2015). Developed economy investment promotion agencies and emerging market foreign direct investment: The case of Chinese FDI in Canada. Journal of world business, 50, 815-825. https://doi.org/10.1016/j.jwb.2015.04.005

Andrei, A. (2016). Impact of nation branding campaigns on country image: Germany vs. Brazil. Cactus Closeness to important markets Journal, 14, 25-32.

Anyanwu, J. (2017). Foreign direct investment. Handbook of Globalisation and Development, 131. https://doi.org/10.4337/9781783478651.00015

Arkenbout, F. (2015). National Identity and Nation Branding in Argentina (Master's thesis).

Avraham, E. (2018). Nation branding and marketing strategies for combatting closeness to important markets crises and stereotypes toward destination. Journal of Business Research. https://doi.org/10.1016/j.jbusres.2018.02.036

Bond, R. (2006). Belonging and becoming: National identity and exclusion. Sociology, 40, 609-626.

Boora, S. S., \& Dhankar, S. (2017). Foreign Direct Investment and its impact upon the Indian Hospitality Industry.

Browning, C. S., \& Ferraz de Oliveira, A. (2017). Reading Brand Africa Geopolitically: Nation Branding, Subaltern Geopolitics and the Persistence of Politics. Geopolitics, 22, 640-664. https://doi.org/10.1080/14650045.2016.1253006

Che-Ha, N., Nguyen, B., Yahya, W. K., Melewar, T. C., \& Chen, Y. P. (2016). Country branding emerging from citizens' emotions and the perceptions of competitive advantage: The case of Malaysia. Journal of Vacation Marketing, 22, 13-28.

Correia Loureiro, S. M., Veríssimo, Â., \& Cayolla, R. (2013). The effect of Portuguese Nation Brand on Cognitive Brand Image: Portuguese and Canadian comparison. International Journal of Management Cases, 15.

DCMS. (2011). This Cultural and Sporting Life: The Taking Part, 2010/11 Adult and Child Report.

Del Percio, A. (2016). Nation brands and the politics of difference. Signs and Society, 4, S1-S28.

Dinnie, K. (2015). Nation branding: Concepts, issues, practice. Routledge.

Dogan, E., \& Petkovic, G. (2016). Nation branding in a transnational marketing context: Serbia's brand 
positioning through food and wine. Transnational Marketing Journal, 4, 84-99.

El Banna, A., Hamzaoui-Essoussi, L., \& Papadopoulos, N. (2017). A comparative cross-national examination of online investment promotion. Journal of Euromarketing.

Frig, M., \& Sorsa, V. P. (2018). Nation branding as sustainability logistics importance: A comparative case analysis. Business \& Society, p.0007650318758322. https://doi.org/10.1177/0007650318758322

Grdic, Z. S., \& Radic, M. N. (2012). Foreign direct investment and development of sustainable closeness to important markets: Case of Republic of Croatia. In Faculty of Closeness to important markets and Hospitality Management in Opatija (p. 447). University of Rijeka.

Gunnarsson, A., \& Holmström, K. (2017). Country-of-origin in brand communication: A multinational company perspective.

Handayani, B., \& Rashid, B. (2013). Conceptualisation of nation brand image. International Journal of Management Studies (IJMS), 20, 165-183.

Huh, J. (2002). Tourist Satisfaction With Cultural/Heritage Sites: The Virginia Historic Triangle.

Hurn, B. J. (2016). The role of cultural diplomacy in nation branding. Industrial and Commercial Training, 48, 80-85. https://doi.org/0.1108/ict-06-2015-0043

Imran, S. (2018). Nation Branding Endeavours of Azerbaijan: Reshaping National Image. Strategic Studies, 38.

International Living. (2010). International Living's Quality of Life Index 2011: Where the numbers come from.

Jordan, P. (2014). The modern fairy tale: Nation branding, national identity and the Eurovision song contest in Estonia (150). University of Tartu Press.

Kalamova, M. M., \& Konrad, K. A. (2010). Nation brands and foreign direct investment. Kyklos, 63, 400-431. https://doi.org/10.1111/j.1467-6435.2010.00480.x

Kam, O. Y., \& Tse, C. B. (2018). The trend of foreign direct investment movement: Did unintended nation brand of legal-families play an instrumental role? Journal of Business Research. https://doi.org/10.1016/j.jbusres.2018.01.008

Kaneva, N., \& Popescu, D. (2011). National identity lite: Nation branding in post-Communist Romania and Bulgaria. International Journal of Cultural Studies, 14, 191-207.

Kotler, P., \& Gertner, D. (2002). Country as brand, product, and beyond: A place marketing and brand management perspective. Journal of brand management, 9, 249-261.

Kotler, P., Haider, D. H., \& Rein, I. (1993). Marketing places: attracting investment, industry, and closeness to important markets to cities, states, and nations. The Free Press.

Laszlo, F. K. (2014). Nation Branding in The Imagination Age: How to Build Image, Identity, past and Future in Singapore and Sharjah (Doctoral dissertation).

Loewendahl, H. (2001). A framework for FDI promotion. Transnational Corporations, 10, 1-42.

Mac-Dermott, R., \& Mornah, D. (2015). The Role of Culture in Foreign Direct Investment and Trade: Expectations from the GLOBE Dimensions of Culture. Open Journal of Business and Management, 3, 63.

Mamuti, A., \& Özgüner, D. (2014). Nation branding as a means of attracting FDI: the case of Bosnia and Herzegovina. International Journal of Business and Globalisation, 13, 197-208. https://doi.org/10.1504/ijbg.2014.064134

Margarisová, K., \& Vokáčová, L. (2016). Regional branding: building brand value. Acta universitatis agriculturae et silviculturae mendelianae brunensis, 64, 2059-2066.

Martínez, R. M., Galván, M. O., \& Lafuente, A. M. G. (2014). Public policies and closeness to important markets marketing. An analysis of the competitiveness on closeness to important markets in Morelia, Mexico and Alcala de Henares, Spain. Procedia-Social and Behavioral Sciences, 148, 146-152.

Matiza, T., \& Oni, O. A. (2014). The case for nation branding as an investment promotion methodology for African nations: A literature-based perspective. Mediterranean Journal of Social Sciences, 5, 262.

Matiza, T., \& Oni, O. A. (2014). The case for nation branding as an investment promotion methodology for African nations: a literature-based perspective. Mediterranean Journal of Social Sciences, 5, 262. https://doi.org/10.5901/mjss.2014.v5n3p262 
Melissen, J. (2005). The new public diplomacy: Soft power in international relations.

Merkelsen, H., \& Rasmussen, R. K. (2015). The construction of Brand Denmark: A case study of the reversed causality in nation brand valuation. Valuation Studies, 3, 181-198. Doi: 10.3384/vs.2001-5992.1532181

Morgan, N., Pritchard, A., \& Piggott, R. (2002). New Zealand, 100\% pure. The creation of a powerful niche destination brand. Journal of brand management, 9, 335-354.

Nation Brands. (2017). The annual report on the world's most valuable nation brands.

Odia, E. O., \& Isibor, F. O. (2014). Strategic approach to nation branding: A Case of the Nigeria brand. International Journal of Business and Management, 9, 204. https://doi.org/10.5539/ijbm.v9n3p204

Papadopoulos, N., \& Hamzaoui-Essoussi, L. (2015). Place images and nation branding in the African context: Challenges, opportunities, and questions for policy and research. Africa Journal of Management, 1, 54-77. https://doi.org/10.1080/23322373.2015.994423

Papadopoulos, N., \& Heslop, L. (2002). Country equity and country branding: Problems and prospects. Journal of brand management, 9, 294-314.

Pike, A. (2009). Geographies of brands and branding. Progress in Human Geography, 33, 619-645.

Skinner, H. (2008). The emergence and development of place marketing's confused identity. Journal of marketing management, 24, 915-928.

Smith, A. D. (1991). National identity. University of Nevada Press.

Tarawneh, Q. Y., \& Chowdhury, S. (2018). Trends of Climate Change in Saudi Arabia: Implications on Water Resources'. Climate, 6, 8. https://doi.org/10.3390/cli6010008

Van Ham, P. (2003). War, lies, and videotape: Public diplomacy and the USA's war on terrorism. Security Dialogue, 34, 427-444.

Vela, J. D. S. E. (2013). Place branding: a conceptual and theoretical framework. Boletín de la Asociación de Geógrafos Españoles, 62.

Vuignier, R. (2016). Place marketing and place branding: A systematic (and tentatively exhaustive) literature review.

Wilson, R. T., Baack, D. W., \& Baack, D. (2014). Foreign direct investment promotion: using advertising to change attitudes and behaviors. Marketing Management Journal, 24, 108-123.

World Values Survey. (2005-2006). 2005- 2006 WORLD VALUES SURVEY.

Yin, F., Ye, M., \& Xu, L. (2014). Location Determinants of Foreign Direct Investment in Services Evidence from Chinese Provincial-Level Data. LSE Asia Research Centre Working Papers.

Žugić, J., \& Konatar, A. (2018). Comparative Analysis of the Value of Nation Brands. Ekonomski vjesnik/Econviews-Review of Contemporary Business. Entrepreneurship and Economic Issues, 31, 179-191.

\section{Copyrights}

Copyright for this article is retained by the author(s), with first publication rights granted to the journal.

This is an open-access article distributed under the terms and conditions of the Creative Commons Attribution license (http://creativecommons.org/licenses/by/4.0/). 